\title{
ENTEROPATHIC HYPOPROTEINAEMIA
}

\author{
BY \\ MICHAEL SIMPKISS and WILFRID SHELDON \\ From The Hospital for Sick Children, Great Ormond Street, London
}

(RECEIVED FOR PUBLICATION MAY 30, 1961)

Schwartz and Thomsen (1957) used the term hypercatabolic hypoproteinaemia to explain the fall in plasma protein in some cases of hypoproteinaemia. In the same year Citrin, Sterling and Halsted (1957) reported a patient in whom hypoproteinaemia was associated with hypertrophic gastritis; by giving ${ }^{131}$ I-labelled human serum albumin intravenously they were able to demonstrate an increased rate of loss of serum albumin due to excretion into the stomach. A similar rate of loss was described by Freeman and Matthews (1958) and Pearson, Veall and Vetter (1958) in their cases of hypoproteinaemia. Gordon (1958, 1959), using intravenous ${ }^{131}$ I-labelled polyvinylpyrrolidone which has a molecular weight similar to that of albumin, was able to recover this substance from the stools in a patient with hypoproteinaemia, and similar results were obtained by Schwartz and Jarnum (1959) and by Young, Levin, Fowler and Miles (1959).

We present a child with hypoproteinaemia in whom there was an increased turnover of ${ }^{131} \mathrm{I}$ labelled human serum albumin due to a leakage into the upper small intestine.

\section{Case Report}

Graham H. was born in March 1952, the first born of parents who are not blood relatives. He was breast fed for five months. At 2 years of age he became listless, vomited after meals, had abdominal distension and began to pass two loose, pale, offensive motions daily. A sample of dried stool contained $33 \%$ fat. At that time his total plasma proteins were $3 \cdot 4 \mathrm{~g} . / 100 \mathrm{ml}$. Coeliac disease was suspected, and for the next year he was given a gluten-free diet, during which time his stools improved. He then returned to a normal diet. Two and a half years later his stools were again large, pale and offensive, there was oedema of the scrotum, and the total plasma proteins were $2.9 \mathrm{~g} . / 100 \mathrm{ml}$., of which albumin accounted for $1.6 \mathrm{~g}$.

At this stage the boy was referred to The Hospital for Sick Children, Great Ormond Street.

On admission, at $4 \frac{1}{2}$ years, the boy appeared plump, and with a distended abdomen, but was small for his age. Height $37 \frac{3}{4}$ in. $\left(95 \cdot 88 \mathrm{~cm}\right.$.), weight $33 \frac{1}{2} \mathrm{lb} .(15 \cdot 08$ kg.). The liver was enlarged to three fingers' breadth below the costal margin and was smooth and firm. The spleen was not palpable. There was considerable ascites and scrotal oedema, but no oedema elsewhere, and there were no other abnormal physical signs. The stools were large, pale, and semi-formed.

Investigations. The blood count was normal; the urine was normal; blood urea $33 \mathrm{mg}$. $/ 100 \mathrm{ml}$. Wassermann reaction was negative. Total serum proteins $3 \cdot 2 \mathrm{~g} . / 100 \mathrm{ml}$. (albumin $2 \cdot 0 \mathrm{~g} . / 100 \mathrm{ml}$.). Liver function tests were normal; serum cholesterol $154 \mathrm{mg} . / 100 \mathrm{ml}$; serum bilirubin less than $0.5 \mathrm{mg} . / 100 \mathrm{ml}$.; and a bromsulphthalein test was normal, $95 \%$ of the test dose being excreted in 45 minutes. A fractional test meal showed no free acid, but there was a normal response to histamine. A barium meal showed no abnormality in the stomach or intestines and, in particular, no evidence of hypertrophic gastritis. A glucose tolerance test produced a rise of $71 \mathrm{mg} . / 100 \mathrm{ml}$. of reducing substances half an hour after the test dose. Analysis of duodenal juice showed digestion of gelatin to a dilution of 1 in 800 ; amylase 400 units and lipase 9 units per $100 \mathrm{ml}$. There was a normal rise in blood $\alpha$ amino nitrogen in the blood after a test dose of casein.

Two biopsies were carried out: biopsy of the liver (1957) showed macroscopically a normal organ; histologically, some increased fibrous tissue in the portal areas, and slight inflammatory cell infiltration and bile duct proliferation was reported. Since that time the liver has become normal in size and consistency. A jejunal mucosal biopsy (1959) was carried out by Dr. Margot Shiner and showed a normal mucosa.

In view of the enlarged liver, normal glucose curve, and later on the normal jejunal mucosal biopsy, a diagnosis of coeliac disease was considered unacceptable, while the normal duodenal juice was held to exclude pancreatic fibrosis. Because of the history of variable oedema accompanied by a low plasma protein level, a diagnosis of idiopathic hypoproteinaemia accompanied by steatorrhoea was made.

Attention was first directed towards the steatorrhoea. An eight-day fat balance on a normal diet containing $45 \mathrm{~g}$. fat showed an average daily absorption of $76 \%$. The addition of 15 grains of bile salts daily to the diet brought no improvement. Six months later the fat balance on a normal diet was repeated, and gave a figure of $86 \%$ absorption. A chylomicron count gave a flat curve with a rise of only 160 chylomicrons three hours 


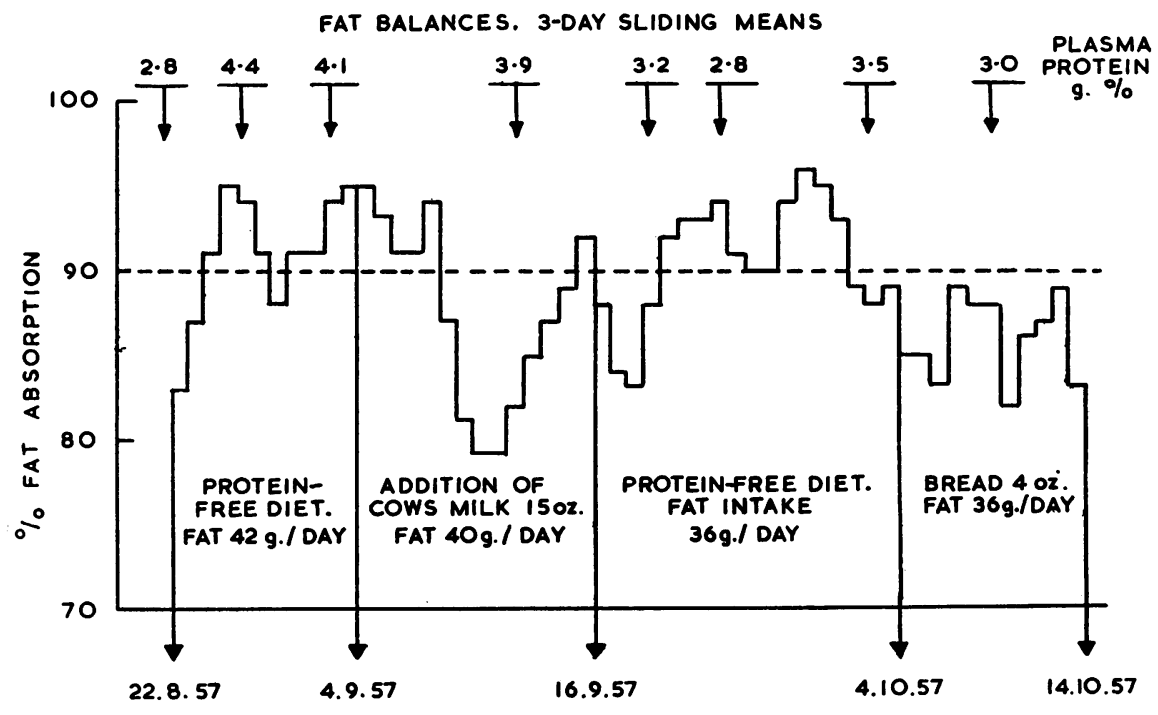

Fig. 1.

after a test dose of fat, although after a test dose of finely emulsified fat, kindly supplied by Professor A. C. Frazer, a rise of 355 chylomicrons in three hours was recorded, suggesting that a defect in fat emulsification was present.

It is now well established that the protein of wheat (gluten) plays an important role in inducing the steatorrhoea of coeliac disease, but seemingly other proteins may at times provoke steatorrhoea. Thus Chaptal, Jean, Dossa, Bonnet, Crastes de Paulet and Navarro (1957) recorded an infant in whom the proteins of wheat, oats and milk were provocative agents, and Davidson and Burnstine (1957) reported an instance of steatorrhoea due to $\beta$ lactoglobin. It was therefore decided to watch the effect on Graham's steatorrhoea of removing the protein in his diet and giving in its place an acid casein hydrolysate ('cymogram': Allen and Hanbury). The diet consisted of 'cymogram' $60 \mathrm{~g}$. with milk fat $40 \mathrm{~g}$. and sugar. The results are shown in Fig. 1. On the protein-free diet fat absorption rose above $90 \%$, and the stools became formed and of normal colour. The addition of $15 \mathrm{oz}$. (425 g.) cow's milk led to a fall in absorption, which rose again above $90 \%$ when milk was withdrawn, but fell when gluten in the form of $4 \mathrm{oz}$. $(113 \mathrm{~g}$.) bread $(9 \cdot 2 \mathrm{~g}$. gluten) was added to the diet. The bread did not contain milk protein. These investigations suggested that dietary proteins were contributing in some way to the steatorrhoea.

On two occasions while the boy was on the protein-free diet his plasma proteins were above $4 \mathrm{~g}$. $/ 100 \mathrm{ml}$. (see Fig. 1), although when having a normal diet his total plasma proteins, estimated on many occasions, had never risen higher than $3.6 \mathrm{~g} . / 100 \mathrm{ml}$., and were often below $3 \mathrm{~g} . / 100 \mathrm{ml}$. The unexpected rise of plasma proteins on a protein-free diet has been noted on four subsequent occasions. On the first three of these occasions dietary protein was replaced by aminosol (Figs. 2 and 3). On the fourth occasion (Fig. 4) a partial casein hydrolysate containing a mixture of di-, tri- and tetra-peptides was given instead of protein. On one occasion, at a time when fat absorption was normal, the replacement of dietary protein by $60 \mathrm{~g}$. of 'aminosol' did not lead to a rise in plasma proteins. It must be mentioned that when dietary protein was replaced by amino acids or peptides about $5 \mathrm{~g}$. protein was given each day as vegetable and fruit protein in order to make the diet palatable. When these diets contained fats they were given as milk or bacon fat.

We were at that time unable to account for the fall in plasma proteins when the diet contained protein. Electrophoresis showed that there was a depression of all plasma protein components. There was no albuminuria and no aminoaciduria. The rise in plasma protein level on protein-free diets could have been due to a loss of water from the intravascular space, but this seemed unlikely because the haemoglobin level did not change when a protein-free diet was given. The alternative possibility of a leak of protein into the lumen of the small intestine was next considered and we are grateful to Dr. Freeman of the Medical Research Council for carrying out the isotope studies involved.

Two investigations were made using ${ }^{131}$ I tagged human albumin given intravenously. In the first the boy was given a gluten-free diet containing milk and meat fats, and in the second a protein-free fat-free diet with aminosol. $10 \mathrm{mg}$. sodium iodide was given twice daily for three days preceding the injections. Normal ${ }^{131} \mathrm{I}$ albumin, 31.1 $\mu \mathrm{c}$, was given intravenously. Twenty-four hours later a tube was passed into the upper part of the small intestine and $2 \mathrm{ml}$. intestinal fluid was obtained 


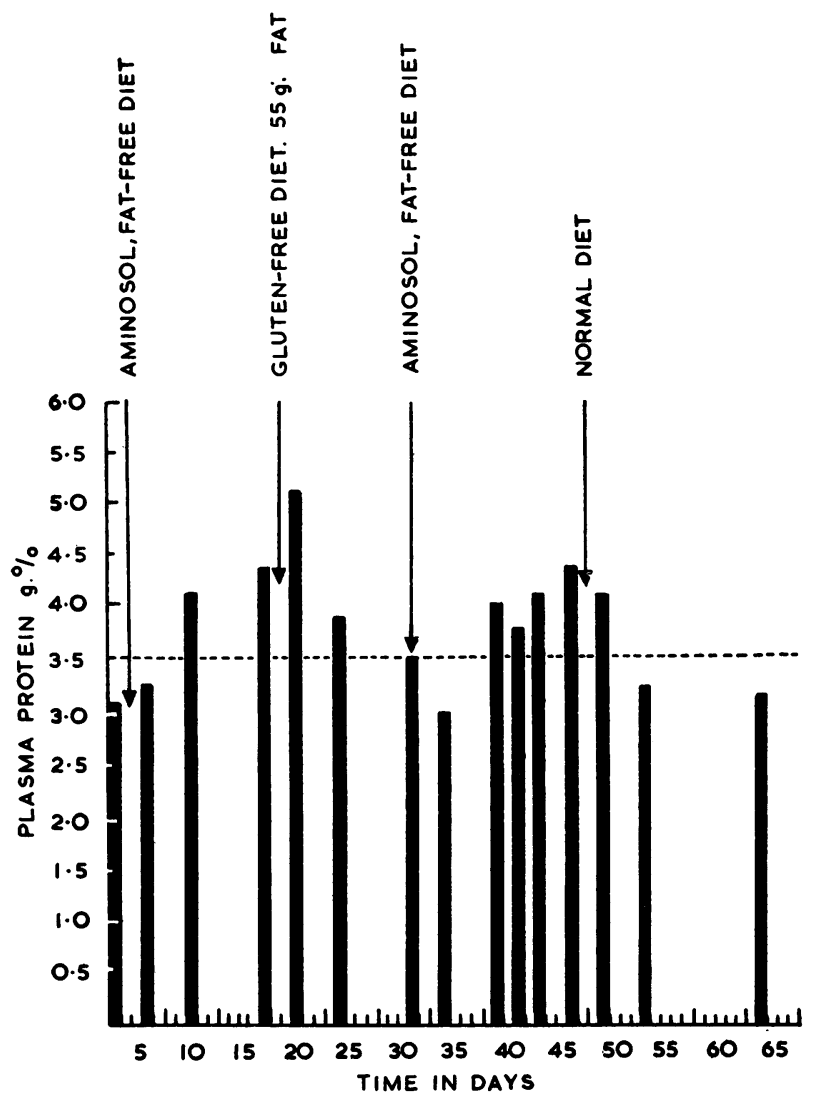

FIG. 2.

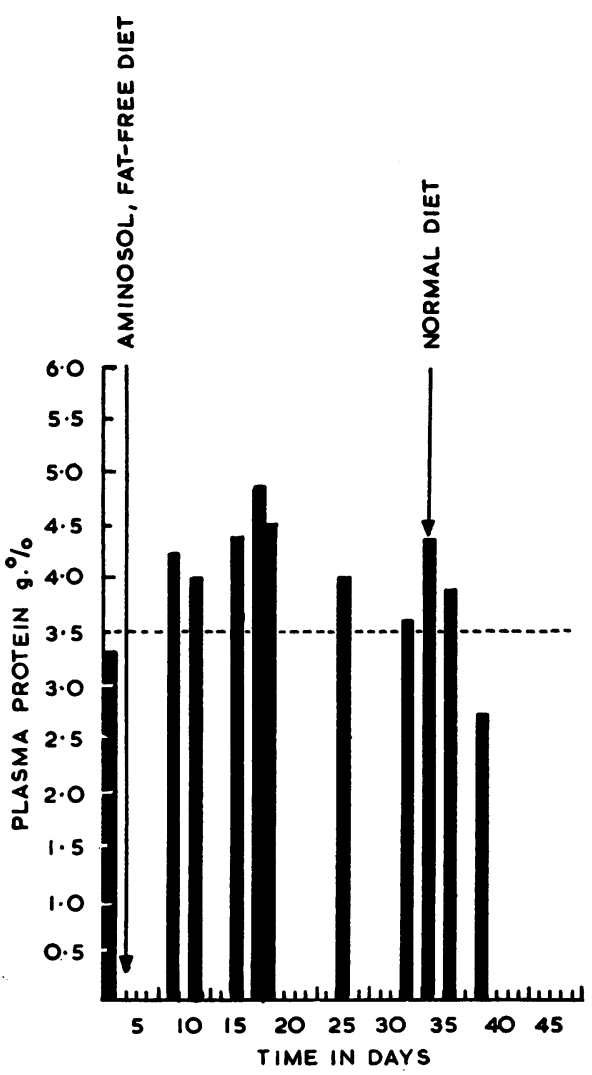

FIG. 3. by suction. Samples of blood and 24-hourly collections of urine and stools were taken before each injection, and daily, for several days afterwards. Radioactivity was estimated in these specimens using a well-type scintillation counter. The intestinal fluid in each experiment was tested with benzidine with negative results. It was examined for labelled proteins using a method described by T. Freeman (personal communication).

The following calculations were made according to the methods described by Freeman and Matthews (1958).

1. Total plasma volume.

2. Protein albumin masses.

3. Catabolism of albumin per 24 hours based on urinary non-protein bound radioactivity related to the mean plasma radioactivity.

In the first investigation, while the boy was on a gluten-free diet, the catabolism of albumin per 24 hours was $45 \%$ of the intravascular albumin mass (normal adults 7 to $11 \%$ ) representing a loss of $8.6 \mathrm{~g}$. per day or $478 \mathrm{mg} . / \mathrm{kg}$./day (normal adults 150 to $190 \mathrm{mg} . / \mathrm{kg}$./day).

In the second investigation, while the boy was receiving the amino acid protein-free diet, the catabolism of albumin per 24 hours was $12 \cdot 5 \%$ of the intravascular albumin mass.

On the gluten-free diet the fluid obtained from the small bowel contained a small amount of labelled protein having the electrophoretic mobility of albumin. There was no haemoglobin in the sample. On the amino acid diet no labelled protein was present in the intestinal fluid obtained. These investigations indicated that while on a gluten-free diet there was a leakage of plasma albumin into the intestine. On neither diet was any labelled protein demonstrable in the urine or stools. The absence of tagged albumin from the stools was presumably due to the excreted protein being digested and the products reabsorbed.

The normal catabolism of albumin in an adult is generally taken to be about $10 \%$ of the intravascular albumin mass per day and if this figure is applied to our patient, then the leak of albumin while he was on a gluten-free diet was of the order of $35 \%$ per day, but fell to $2.5 \%$ per day while on a protein-free diet. It seems more likely that the reduction was due to a diminution of the intestinal leak than to diminished catabolism, a conclusion which is supported by the 


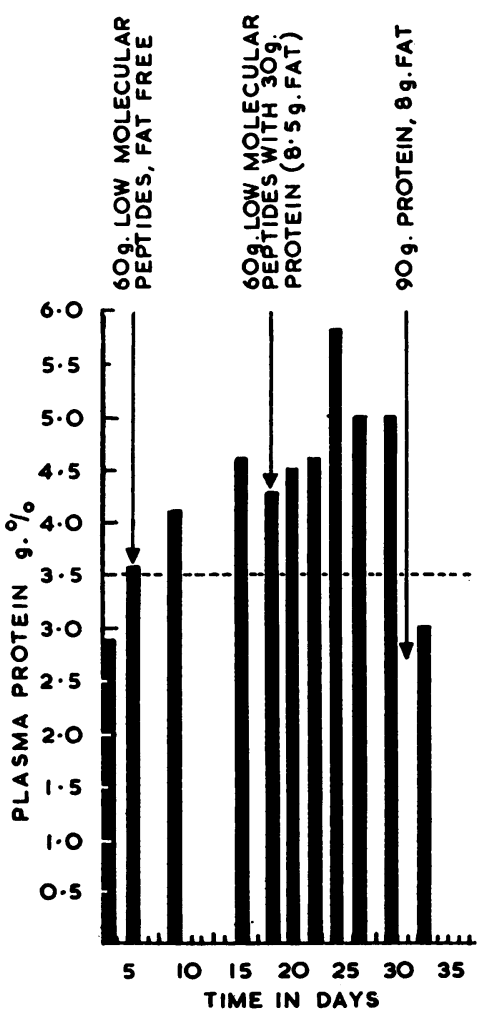

FIG. 4.

failure to recover labelled albumin from the intestinal contents in the second investigation.

An attempt was then made to find out whether the leak was caused by any specific protein, and whether the leak was influenced by ingested fat. Several diets were given, each for a period of three weeks: a gluten-free diet (meat and milk fats $50 \mathrm{~g}$.); a diet containing vegetable proteins but no animal protein (soya fat $50 \mathrm{~g}$.); a diet containing animal proteins but no vegetable protein (vegetable fats $50 \mathrm{~g}$.); a diet containing $50 \mathrm{~g}$. mixed protein and $5 \mathrm{~g}$. meat and milk fats; a diet containing $90 \mathrm{~g}$. mixed protein and $5 \mathrm{~g}$. meat and milk fats. The level of plasma protein remained low throughout these régimes, varying from 2.7 to $3.5 \mathrm{~g} . / 100 \mathrm{ml}$. Cutaneous tests with a wide range of food proteins failed to give an allergic reaction.

It was concluded that the leak of plasma protein was connected with the presence of protein in the diet, but not with any specific protein, and that the leak was not influenced by the presence or amount of dietary fat.

In view of the apparent check on intestinal protein leakage which occurred when dietary protein was replaced by amino acids it seemed worth while to find out whether low molecular peptides would have a comparable effect. Allen and Hanbury kindly prepared for us a partial casein hydrolysate in which all protein was broken down to di, tri and tetra peptides. Chromatography showed no amino acids present. The effect of adding $60 \mathrm{~g}$. of this preparation each day to a protein-free diet is shown in Fig. 4. After 14 days of this régime the plasma proteins rose from $2.9 \mathrm{~g}$. to $4.6 \mathrm{~g} . / 100 \mathrm{ml}$. Three days later $30 \mathrm{~g}$. of ch.cken and fish were added to the diet; 15 days then elapsed before the plasma proteins fell to less than $3.5 \mathrm{~g}$. $/ 100 \mathrm{ml}$. We have been unable to find a satisfactory explanation to account for this lag. It was concluded that low molecular peptides were probably as effective as amino acids in arresting the intestinal leak.

\section{Summary}

A child with hypoproteinaemia due to a leakage of protein into the upper small bowel is described. The replacement of dietary protein by amino acids or peptides of low molecular weight was associated with a rise in plasma proteins. An experiment using ${ }^{131}$ I-tagged human albumin suggests that this effect was produced by diminishing the intestinal leak of protein. The dietetic modifications which we employed lessened the accompanying steatorrhoea. We were unable to show that the harmful effect of dietary protein on the intestine was due to any specific protein.

We are grateful to Dr. Margot Shiner for carrying out the jejunal biopsy; to Professor A. C. Frazer for supplying us with finely emulsified fat; to Dr. T. Freeman of the National Institute for Medical Research, Mill Hill, for carrying out the isotope studies; and to Dr. F. A. Robinson of Messrs. Allen \& Hanbury for making the low molecular peptide mixture.

\section{REFERENCES}

Chaptal, J, Jean, R., Dossa, D., Bonnet, H., Crastes de Paulet and Navarro, M. (1957). Maladie coeliaque par intolérance à la gliadine de froment et d'avoine et aux produits lactés. Pédiatrie, gliadine

Citrin, Y., Sterling, K. and Halsted, J. A. (1957). The mechanism of hypoproteinemia associated with giant hypertrophy of the gastric mucosa. New Engl. J. Med., 257, 906.

Davidson, M. and Burnstine, R. (1957). Steatorrhea related to a factor in cow's milk. A.M.A. J. Dis. Child., 93, 45.

Freeman, T. and Matthews, C. M. E. (1958). Analysis of the behaviour of I131-albumin in the normal subject and nephrotic patient. Strahlentherapie, Sonderband, 38, 283.

Gordon, R. S., Jr. (1958). The preparation of radioactive polyvinylpyrrolidone for medical use. J. polym. Sci., 31, 191 vinylpyrrolidone for medical use. J. polym. Sci., 31, 191. (1959). Exudative enteropathy, abnormal permeability of the gastrointestinal tract demonstrable with labelled polyvinylpyrrolidone. Lancet, 1, 325.

Pearson, J. D., Veall, N. and Vetter, H. (1958). A practical method for plasma albumin turnover studies. Strahlentherapie, Sonderband, 38, 290.

Schwartz, M. and Jarnum, S. (1959). Gastrointestinal protein loss in idiopathic (hypercatabolic) hypoproteinaemia. Lancet, 1, 327. proteinaemia; case cxamined by 131 I-labelled albumin. Brit. med. J., 1, 14 .

Young, W.' F., Levin, B., Fowler, J. F. and Miles, J. M. (1959) Gastrointestinal protein loss in severe malabsorption complicated by idiopathic (hypercatabolic) hypoproteinaemia. Lancet, 